\title{
Representative Board Governance: What Role Do Nonprofit Board Directors Have in Representing the Interest of Their Constituents?
}

\author{
Anthony Piscitelli, Conestoga College, \& Sean Geobey \\ University of Waterloo
}

\begin{abstract}
The current ethos of most nonprofit boards of directors focuses on role clarity between board directors and the executive director. The board's role is to collectively set strategic direction and provide oversight while leaving day-to-day operations to staff. Yet, many individual directors join a board to make an impact on the organization by addressing very specific operational concerns and/or to represent a stakeholder group, and this creates tension at the board table. This article explores whether there is necessarily a trade-off between the representative and good governance roles of a nonprofit board director. It will demonstrate that the tension between representing member interests and governing nonprofits is a false dichotomy. Reconciling these two interests offers some potential avenues for improved organizational accountability.

\section{RÉSUMÉ}

La plupart des conseils d'administration pour les organismes sans but lucratif (OSBL) tiennent à ce que le rôle des membres du conseil soit distinct de celui du directeur général. Le rôle du conseil est d'établir l'orientation stratégique de l'organisme et d'en assurer la supervision tout en confiant la gestion quotidienne au personnel. Souvent, cependant, les membres se joignent à un conseil en vue de résoudre des problèmes opérationnels très précis ou de représenter des partis pris spécifiques, ce qui peut soulever des tensions. Cet article explore s'il y a nécessairement incompatibilité entre le rôle de représentation et celui de bonne gouvernance sur le conseil d'un OSBL. L'article démontre que la tension entre la représentation des intérêts des membres et la gouvernance d'un OSBL s'avère être une fausse dichotomie. De surcroît, réconcilier ces deux intérêts pourrait avoir comme effet d'améliorer la responsabilité organisationnelle.
\end{abstract}

Keywords / Mots clés: Governance; Board of directors; Agency theory; Representation; Nonprofits / Gouvernance; Conseil d'administration; Théorie de l'agence; Représentation; Organismes sans but lucratif 


\section{Piscitelli \& Geobey (2020)}

\section{INTRODUCTION}

Members of boards of directors bear the ultimate responsibility for the success and viability of an organization (Chait, Ryan, \& Taylor, 2011; Gill, 2005; Ricardo-Campbell, 1997). For the many small nonprofits run by volunteers, this might be quite direct as they are performing much of the nonprofit's day-to-day work. As a nonprofit grows, however, and the board indirectly manages more resources and an increasingly complex stakeholder network, the nature of this relationship changes. Governance theory suggests the boards of directors of nonprofit organizations should fulfill this responsibility by setting the organization's strategic direction and providing fiduciary oversight, without wading into the organization's operations (Carver, 2006; Chait et al., 2011; Drucker, 1990; Gill, 2005). In contrast, agency theory (Jensen \& Meckling, 1976) argues the central purpose for the board of directors is to represent the interests of the organization's owners. Since nonprofits do not have residual claimants, the rights of "ownership" in a nonprofit are weaker than in a for-profit or cooperative model (Hansmann, 1980). However, when the membership communicates its concerns to the board of directors and to individual directors, these concerns are typically expressed as operational issues (Carver, 2006; Danielson, 2017).

Since most boards have developed models that separate board members from involvement in operational matters, addressing member concerns is considered the role of management. Yet, agency theory argues boards must ensure management is acting in the interests of the membership. Fulfilling the board's obligation as agents of the membership is, therefore, a challenge within the common governance systems practiced by boards of directors of nonprofit organizations, yet these issues of representation are of critical importance to them. This article's key research question is this: Is there necessarily a trade-off between a director's role as an effective representative and as a good governor in a nonprofit organization?

This article will demonstrate that the tension between representing member interests and governing nonprofits is a false dichotomy. Since many of the services being delivered by nonprofits are being done so on behalf of governments, understanding how representation functions in the nonprofit sector helps to explain how well democracy is functioning at a local level. The theoretical underpinnings of this article will draw from agency theory to analyze the main nonprofit board governance models used in Canada and assess how they approach the issue of a potential representative role for directors. This article incorporates insights from Albert Hirschman's (1970) Exit, Voice, and Loyalty: Responses to Decline in Firms, Organizations, and States to argue for a more direct incorporation of representation into nonprofit boards.

\section{NONPROFIT GOVERNANCE AND GOVERNMENTS}

The consequences of ensuring good governance in nonprofits is important and ties directly into their evolving relationship with governments. Revenue from governments in Canada accounted for about 50 percent of the $\$ 169.2$ billion in economic activity generated by the nonprofit sector in Canada in 2017 (Statistics Canada, 2019); Statistics Canada (2019) has broken down the nonprofit sector into three categories, providing information on the percentage of revenue each category receives from the government. Community nonprofit institutions received 30.8 percent of their funding from the government. Government nonprofit institutions received 72.9 percent of their income from government sources. While business nonprofit institutions received only 1.4 percent of their funding from governments. The sector receives funding from all levels of government-federal, provincial, and municipal-to deliver services through 2.4 million employees (Imagine Canada, 2006). Government is increasingly working with the nonprofit sector as a mechanism to outsource services and in recognition that governments need partnerships to solve the most complex problems facing society (Phillips \& Levasseur, 2004). Thus, in many ways, nonprofit organizations are becoming an extension of government services (Hall \& Reed, 1998), and this has implications for how citizens in society exercise their democratic voice. Indeed, this has critical implications for the governance of those nonprofits themselves, as directors whose primary impetus for joining a board is to represent a particular group of constituents-an exercise in democratic voice-take on a broader mantle of governance responsibilities to serve the organizations whose boards they join. 


\section{Piscitelli \& Geobey (2020)}

Theories of the welfare state and theories of the voluntary sector are inadequate to explain why the government relies so heavily on the nonprofit sector to deliver services (Hall \& Reed, 1998; Salamon, 1987). Theories of the welfare state suggest that market failure coupled with government failure can explain much of the nonprofit sector: when the market cannot provide a good at a socially optimal level, but the good cannot command support from a majority of voters, then the nonprofit sector often fills the gap. However, what this approach misses is that most nonprofit sector funding comes from government sources (Salamon, 1987). Theories of the voluntary sector suggest nonprofits exist to address a contract failure problem that occurs when the service recipient and the funder of the service are not the same people (Hansmann, 1980; Salamon, 1987). In these circumstances, it is either impossible or overly costly for a donative funder to directly observe service or product quality (Hansmann, 2013). The lack of direct quality assurance means that service providers could shirk service delivery to reduce costs and increase profits. Because of this possibility, the non-distribution of profits that the nonprofit legal form imposes provides an assurance to funders that resources will not be funnelled from service quality toward dividend payments. Yet, government funding often is tied to extensive regulations and reporting mechanisms, suggesting the non-distribution constraint is insufficient as a quality assurance tool (Levasseur, 2018; Phillips \& Levasseur, 2004; Salamon, 1987). Lester Salamon (1987) proposes "third-party government" (p. 29) as the explanation for nonprofit activity along these lines. From this perspective, nonprofits are a mechanism for providing programming across large geographic areas while differentiating services according to local needs. By contracting different nonprofits to offer local services, these services can meet the needs of the local population without creating political difficulties. In many cases, the services are provided by organizations that were helping those in need before the government began trying to address the problem. This contracting also avoids the need for the duplication of organizational structures; governments provide representation at the system level by ensuring that services are provided to constituencies and do so without becoming involved in specific service delivery. Governments attempt to ensure delivery meets their requirements through complex accountability agreements, legislation, and regulations, thus ensuring services are delivered in a way consistent with the government's wishes (Levasseur, 2018; Phillips \& Levasseur, 2004). This allows elected officials to say they are meeting community needs without risking being blamed for the dissatisfaction that some people feel about how that need is being met. Instead, day-to-day complaints will be directed toward the nonprofit organization's board and staff, rather than toward government and elected representatives. While this outsourcing may solve problems for elected politicians, it moves questions of representation to the nonprofit sector. However, these issues vary depending on the type of nonprofit organization in question.

\section{TYPES OF NONPROFITS}

Before delving into issues involving democratic representation and the government contracting of nonprofits, it is important to categorize the different types of nonprofit organizations and to understand both the basic functions of their governance and how these functions relate to a given organization's membership. Nonprofit boards are governed by a board of directors. The board of directors is "an organized group of people with the authority collectively to control and foster an institution that is usually administered by a qualified executive and staff' (Houle, 1990, p. 6). How these boards are formed varies depending on the type of nonprofit organization in operation.

First, it is worth considering the size of a nonprofit's board of directors. Mel Gill (2005) notes that smaller nonprofits require their boards of directors to be much more involved in the operations of the nonprofit. Many small nonprofits do not have staff and therefore rely exclusively on volunteers to do the work of the organization. Typically, these small nonprofits' boards are made up of a few individuals who happen to volunteer for the organization in other capacities. Often, little thought is given to the board functions, as board members for these nonprofits are primarily focused on the organization's work, rather than governance. However, Gill (2005) notes that even in these circumstances it can be helpful for the board to divide matters into those that involve governance and those that involve operations. In this way, the role of the board and the role of the volunteer staff member can be distinguished. Larger nonprofit organizations typically do not 


\section{Piscitelli \& Geobey (2020)}

face these challenges, as the staff and board function are clearly separated. However, depending on the operating approach of the board, this is not always the case.

Larger nonprofit organizations can be divided by placing them on two axes: donative versus commercial nonprofits, and mutual versus entrepreneurial nonprofits (Hansmann, 1980). Donative nonprofits primarily receive income from donations, whereas commercial nonprofits charge for goods and services. On the other axis, mutual nonprofits are primarily controlled by the members who benefit from their goods or services, and entrepreneurial nonprofits are primarily led by self-selecting and self-perpetuating boards. These spectra provide four categories of nonprofit organization: "1) donative mutual; 2) donative entrepreneurial; 3) commercial mutual; and 4) commercial entrepreneurial" (Hansmann, 1980, p. 842). Donative mutual organizations may be charitable (serving an altruistic purpose) or member servicing (e.g., fraternal organizations) in their orientation. In practice, charitable organizations may have a formal membership that is a small subset of clients or community members interested in the organization. In these circumstances, other stakeholders may be considered part of the moral ownership (Carver, 2006).

The self-selecting board of a donative entrepreneurial nonprofit holds the moral leadership of the organization perpetually and will often expand the board of directors to include different communities and skill sets to bolster this leadership. Here, once again, the moral ownership of the organization is likely broader than the formal membership. Commercial mutual organizations are typically owned by a group that uses the nonprofit's services (i.e., the membership). Finally, commercial entrepreneurial nonprofit organizations receive funding through service delivery and have a self-perpetuating board of directors. Many of the largest nonprofits, including hospitals and universities, use this structure. The formal membership of these organizations is the self-perpetuating board of directors. However, the moral ownership is broader and includes many other stakeholders. Throughout this article, any reference to the membership of an organization is designed to include the formal members as well as the moral ownership, which includes stakeholders who access services, donors, volunteers, and community members who support the existence of the organization. Due to the unique structure of nonprofits, nonprofit boards should treat these moral owners in the same manner as formal owners of an organization would be treated according to agency theory.

\section{THE PRINCIPAL-AGENT PROBLEM}

Recognizing that organizations are simply legal fictions, it is logical to ask: Why do organizations require boards of directors?

The role of the board in managing principal-agent problems is critical to answering this question. In businesses, principals invest capital in companies to make a profit. It is in the managers of a company's self-interest to maximize their own salaries and benefits, even if this comes at the expense of the investors. Yet, the managers need the investors' money to successfully operate the business. The agency problem, therefore, causes the principals to monitor and control the behaviour of the agent, and these activities have a cost (Jensen \& Meckling, 1976). The boards themselves are agents of their principles, and the process of electing them is intended to allow the principals to exert their control.

In the nonprofit sector, donations generate an additional source of principal-agent tensions because those who purchase goods and services are generally not those who consume them (Olson, 2000). Because of this, donors are not aware of the quality of services provided to the recipients, and thus they require a monitoring function (Brown, 2005). The restrictions of a nonprofit structure provide some check against this donor-consumer issue by limiting the potential financial rewards for directors and managers who might shirk their obligations and reduce the quality of their outputs to take the gains as profits (Hansmann, 1980). This is not to suggest that nonprofit boards do not perform important governance functions. With mutual organizations, for example, the clients themselves elect the board to perform the quality-check function. In entrepreneurial organizations, by contrast, the ownership is murky, as both the funders and client can be seen as owners. 


\section{Piscitelli \& Geobey (2020)}

The funders have a clear expectation that their services will benefit the clients, while the clients have an obvious interest in receiving effective services. Issues of voice and exit among funders and clients thus become relevant.

\section{POWER AND REPRESENTATION}

In a seminal work on democratically structured, member-based organizations, Hirschman (1970) introduces three concepts—exit, voice, and loyalty-and these are highly relevant to the success and democratic representation of nonprofit organizations. Exercising voice is a mechanism by which a customer, client, or donor can attempt to achieve change. The other option for dissatisfied individuals is to exit an organization. The exit option means that a customer, client, or donor has chosen to either not exercise voice or to stop exercising voice and stop using the organization's goods or services or to stop donating. The exit option may mean that the voice option is not used. This is a major risk for institutions, as a silent exit means the organization does not learn about its problems and therefore does not correct them. Hirschman (1970) explains this issue using a hypothetical public school where students leave for a charter school; this exodus causes the public school to deteriorate further instead of fixing its problems. Individuals who feel a strong sense of loyalty-often active volunteers in many nonprofits—-then become an important mechanism of feedback for the board of directors and management of an organization, as exercised through their voice. It is in an organization's self-interest to build and enhance the loyalty of its members by being responsive to their wishes. When this occurs, it increases the likelihood of further feedback and creates a virtuous cycle where loyalty leads to increased voice and a decline in exits. Unfortunately, in practice, short-term interests often negate this virtuous cycle. The board, therefore, should be especially attentive to the voice and exit actions of the organization's membership, as the exit of members can indicate that management may not be effectively responding to issues facing the organization (Jensen \& Meckling, 1976).

In circumstances where an organization is not responsive to members' interests and substitution options exist, members-including donors and clients - will exit the organization by withdrawing their patronage or support. If substitutes do not exist, as is often the case in the nonprofit sector, the membership will attempt to exercise its voice. If this voice is not heard, the organization will lose members, who will either join other nonprofit organizations or leave the nonprofit sector entirely. When a nonprofit organization's membership has few exit options, it also increases the importance of reputational risks. If member voices are not heard internally, it is likely that they will voice their displeasure about the organization externally. This can impact donations for donative nonprofits and sales for entrepreneurial nonprofits. If these actions force an organization to become more responsive to the membership, it will likely be in the long-term interest of the membership and organization. It is the role of the representative director to rise to this challenge, which will be discussed shortly. However, before explaining the challenges the representative director faces, it is important to understand how the role of the board is understood according to current governance paradigms.

\section{THE ROLE OF THE BOARD}

Fundamentally, a board of directors exists to govern an organization. Georg Von Schnurbein (2009) explains that the role of the board is to provide "global leadership and ensure completion of the organization's purpose, legitimacy, and accountability" (p. 100) as well as internal and external stakeholder relationships. This approach contrasts the strategic and oversight role of the board with the role of staff members, who are responsible for day-to-day operations. While it provides protection for politicians and governments, this approach raises issues of representation for individuals receiving services from nonprofit sector organizations. If the government is providing services by outsourcing them, how can democratic mechanisms ensure these services meet the community's needs?

Scholars have developed numerous categorization schemes to show the different ways boards of directors approach their governance role. There are key legal duties board directors must consider in their performance. They have a duty 


\section{Piscitelli \& Geobey (2020)}

of care, which involves making informed decisions on behalf of the organization; a duty of obedience to ensure the organization stays aligned to its mission and articles of incorporation; and a duty of loyalty, which requires acting in the best interest of the organization (Tschirhart \& Bielefeld, 2012). This duty of loyalty is also often referred to as a fiduciary duty to the organization. Beyond these core requirements, the appropriate role of a board is quite contested among scholars, policymakers, and practitioners.

In defining broad approaches to nonprofit governance, different scholars draw different boundaries. Stephen Block (2014) breaks out three approaches to governance: a traditional hierarchical model taken from Cyril Houle (1990), a policy governance approach taken from John Carver (2006), and non-traditional approaches that involve more flexible approaches to decision-making and authority. Alternatively, Pat Bradshaw, Bryan Hayday, Ruth Armstrong, Johanne Levesque, and Liz Rykert (2007) classify five approaches to nonprofit governance: Carver's (2006) policy governance model, which focuses on means-ends distinctions; constituent representation, which is focused on representing key stakeholder groups; entrepreneurial, where the board outlines means, ends, and limitations; emergent cellular, which focuses on ad hoc organizational teams; and a proposed vector model, which integrates elements of the other four. Gill (2005) lists nine types of nonprofit boards: 1) operational, 2) collective, 3) management, 4) constituent representation, 5) traditional, 6) resultsbased, 7) policy governance, 8) fundraising, and 9) advisory. He suggests these board types run on a continuum from most involved in operations to least involved. While these classification schemes each has differences, they all mention the traditional approach and Carver's (2006) policy governance model, which is where this review begins.

Under the traditional model, the board of directors would play a role in overseeing operations alongside its governance role. Committees were typically developed to mirror staff functions (Gill, 2005). In this approach, boards would commonly become involved in operational matters related to programming, finances, and human resources functions (Gill, 2005). The chair was typically a powerful role, often serving as the primary reporting relationship for the executive director.

The policy governance approach was developed by Carver (2006) in the early 1990s as a response to the traditional approach. A board using policy governance focuses on the distinction between ends and means; the board decides the organization's ends, and the means to achieve those ends are left entirely up to the staff. By defining governance as primarily focused on achievement and the avoidance of behaviours, Carver (2006) provides a clear role for the board and a clear role for management, though the ends-means distinction still leaves a role for boards to interact with external parties.

The results-based approach is of particular interest, as it likely the most common model in use by Canadian nonprofit organizations that have formalized governance structures, though it may not always be referred to by this name. The results-based approach tries to craft a balance between Carver's policy governance model and traditional approaches (Gill, 2005). The results-based model does not use some of the more complex elements of the Carver model (such as stating all policies in the negative), and it does not require the board to stay fully out of operations. In the results-based approach, boards can become involved in times of crisis but board involvement in operations is typically limited (Gill, 2005). Essentially, the results-based model and the Carver model seek to focus boards on strategic issues.

Peter Drucker (2005), echoes the emphasis on strategy for a results-based board. He provides a list of three things that create successful governance in a nonprofit. First, the organization requires a clear governance structure that is focused on adhering to the organization's mission and achieving results. This first point, therefore, highlights the importance of strategy. Second, the organization needs both an effective board and an effective executive officer. Third, the organization needs a collegial relationship between the board and the executive officer. This collegial relationship is important to note when exploring how a board of directors can perform a representative function without interfering in operations. 


\section{Piscitelli \& Geobey (2020)}

Before exploring operations, Gill's (2005) seven functions of a board should be highlighted: 1) establishing the mission, 2) providing financial stewardship, 3) overseeing human resources, 4) monitoring performance, 5) community representation, 6) managing risk, and 7) ensuring proper management during times of organizational crisis. Two items on this list-monitoring performance and community representation - tie into the role of a director as a representative. Community representation, according to Gill (2005), involves the promotion of the organization, representing community interests at board meetings, ensuring stakeholder representation during the nominating process, and "facilitating stakeholder input to planning" (p. 64). These four sub-functions of community representation demonstrate that, according to results-based governance, boards should play a role in representing membership interests as one of their core functions. A great deal of research suggests that strong board governance and organizational success are related (Bradshaw, Murray, \& Wolpin, 1992; Brown, 2005; Green \& Gerber, 2008; Herman \& Renz, 1997, 2000; Olson, 2000). But effectiveness as a direct result of monitoring performance is not as straightforward as it may seem since different stakeholder groups determine organizational effectiveness using different criteria (Herman \& Renz, 1997). Consequently, for boards attempting to evaluate organizational performance, the process must be done in a manner that allows for diverse viewpoints to be heard and understood. Yet, it often creates tension when a board has a director focused on responding to these diverse views.

\section{THE CHALLENGE OF REPRESENTATION}

When a customer, client, or donor of a member-driven nonprofit is dissatisfied with organizational performance, they may seek to join its board of directors. Yet, conflict often arises within boards when new directors join the board with the expressed goal of representing constituents or implementing a platform. Houle (1990) highlights that when board directors join on a platform, they are often not aware that the responsibilities of the board go beyond addressing one or two specific issues. This type of board director, one who joins a board with the goal of implementing a platform or representing a group of constituents or stakeholders, will be defined as the representative director. The representative director believes part of their job is to represent the viewpoint of groups of stakeholders at board meetings. This viewpoint will be a subcomponent of the wider set of beliefs brought to the role. Therefore, the representative director may range in overall performance from a high-functioning director to a serious problem for the board. For example, a director elected with a focus on adding a new program who has no interest in discussing anything else can be a serious problem. Alternatively, a director wishing to focus on adding a new program who also recognizes this advocacy must be conducted within the confines of the duties of care, obedience, and loyalty may be an asset to the board.

In a lengthy list of problems with some board directors, Houle (1990) includes two potentially related to the representative director. The first concern involves board directors who join a board with minimal interest in the role of governing but a high level of focus on one or two issues the organization faces. In these circumstances, the board director is simply not contributing enough, and this leaves the rest of the board to pick up the slack. The second concern involves directors who "may have specific interests or motives that adversely affect their judgement or that cause them to use their positions to gain unfair or underhanded advantages" (p. 17). These directors make decisions that create a personal gain, which is a clear violation of their fiduciary duty. However, Karine Levasseur (2018) echoes these concerns in a study of nonprofit daycare providers that shows how difficult it is to ascribe motives to directors. She shows that some directors make decisions for personal, rather than professional reasons. At times, however, a board director may not be motivated by personal gains but because they believe the interests of a group they represent are not being addressed by the organization. Neither type of problem board director discussed by Houle (1990) is limited to the representative board director, but these problems may be more common among representative directors.

Drucker (2005) opposes the very idea of democratically electing boards. His chief concern is not the election process itself but that the process leads to directors running on platforms rather than being selected for the skills they can bring to the board. Houle (1990) argues that establishing the voice of client services may be important through client councils, 


\section{Piscitelli \& Geobey (2020)}

but the board itself is not the appropriate place for clients themselves to sit, as they may represent their own niche stakeholder community rather than the organization as a whole. Though not opposed to the presence of clients on boards, Alan Broadbent and Franca Gucciardi (2017) raise the difficulty for directors in distinguishing what is in the best interest of the organization from what is in the service recipients' interest. Since a board director's legal fiduciary duty requires focusing on the organization's interest, this problem is especially pressing. Despite raising concerns associated with clients serving on boards, Broadbent and Gucciardi (2017) highlight the importance of a board being "connected to the people it is serving and includ[ing] their voices in its work" (p. 89). This raises a question as to why the client's perspective is important. If it is as important as implied, the representative board director, whether elected or appointed, would seem an ideal mechanism to provide the voice of the people an organization serves at the board table.

Much of this criticism may be the result of over applying a corporate governance model in which a small group of shareholders are effectively able to hire and appoint all the directors to a nonprofit context. In the corporate realm, much of the core expertise of governance is expected to exist primarily on the board itself. Yet in a nonprofit context, this may not be wholly appropriate if different stakeholder groups are to be represented. A completely different set of models coming from elected governments, particularly local governments, is built around representatives who do not have all the required financial and legal expertise (see Figure 1). As a consequence, civil servants in municipal governments become adept at providing expertise framed in plain language, which allows elected representatives to support effective decision-making. In this model, the civil servants provide expert technical advice and the elected representatives focus on being responsive to constituents' interests (Fenn \& Siegel, 2017).

Figure 1: Municipal public policy development

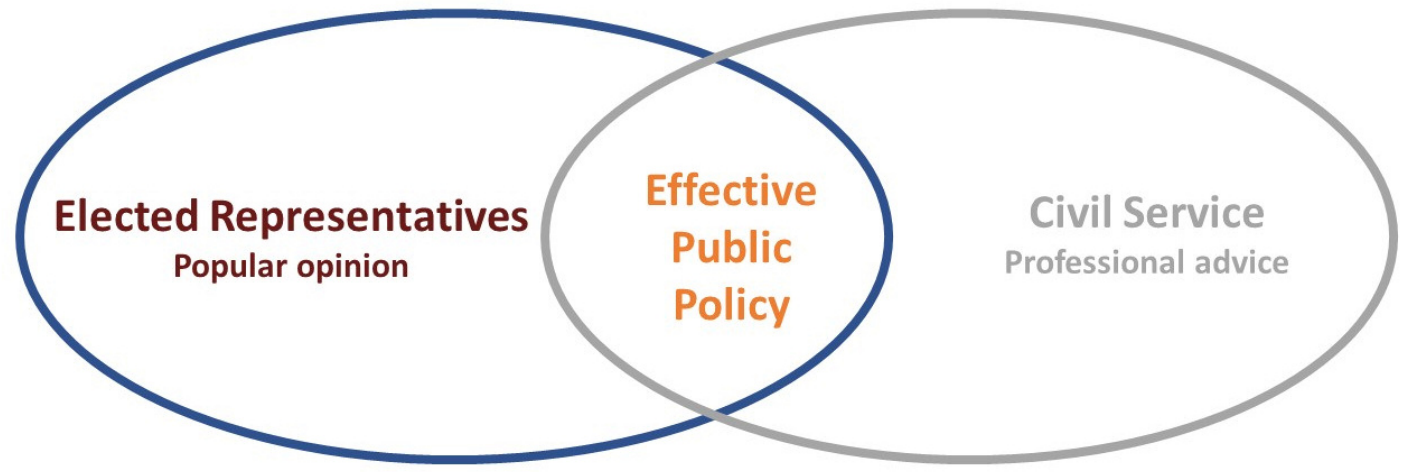

Source: Fenn \& Siegel, 2017

\section{ADDRESSING THE REPRESENTATIVE DIRECTOR}

The necessity of being attuned to the needs of membership is a common theme in governance models. In the policy governance model, which is a useful example as it has the clearest distinction between governance and operational tasks, understanding membership interests is recognized within the "linkage to the ownership" (Carver, 2006, p. 199) function. Carver (2006) recognizes the importance of the board representing the interests of the ownership, suggesting boards should ensure they have mechanisms to hear the concerns of the membership. He argues that directors should "abstract up" (Carver, 2006, p. 243) an operational concern to a board-level strategic concern with an example:

[If] the board is worried about late-working employees going to their cars in a dark parking lot, it would abstract that concern up to its value about endangering staff in any way. The next level above that one might be the board's value about prudence and ethics with regard to staff in general, but it is likely to have already covered that broad issue. having thus abstracted up a little too far, the board would then come down just a little and 


\section{Piscitelli \& Geobey (2020)}

discuss the policy that would deal with the highest form of the issue it has not yet addressed (general endangerment). (Carver, 2006, p. 243)

Unfortunately, the policy governance model's complexity makes it difficult for board directors to understand how to place an item appropriately on the agenda for discussion. A new board director, in particular, may find it difficult to contribute; this makes it likely that a representative director will become frustrated and a disruptive, rather than constructive, influence on the board. Understanding this complicated practice is simply not realistic to expect from new board directors. Instead, an experienced board director-ideally the chair-should help the new board director work the issue from the low-level concern up to a higher-level issue that can be understood at the board table when using the policy governance model.

While results-based governance may make it easier for newly elected representative directors to contribute, there is still a steep learning curve for new directors. The chair of the board, the executive director, and other experienced directors still have an important role to play. It is incumbent on the board as a whole to create an environment where the representative director has constructive avenues to voice concerns about the organization. The representative director needs latitude in sharing concerns without immediate attempts to silence their view or persuade them that what they are asking for is not possible. At times, particularly early in a new director's tenure, these concerns will be operational in nature and out of scope for the board of directors. In these circumstances, the board's chair should help the director understand what the board's function is and what is out of scope as purely an operational concern. The executive director also plays a role in creating a climate that welcomes insights from directors. An effective management team should view information from the representative director as valuable insight into member perspectives and consider if this new information about operational issues changes the approach that should be taken. Finally, the board should strive to understand what governance issues are behind the operational concerns of the representative director. Ultimately, the board's goal should be to create a trusting environment where all directors feel comfortable sharing their viewpoints. The willingness and desire to change is perhaps the greatest gift the representative director brings to an organization. The representative director, even if unsuccessful in achieving their platform, is driving the organization forward by being open to change.

There is a caveat: Just because someone shares personal characteristics with a segment of stakeholders, it does not mean their voice necessarily represents that group as a whole. Instead, this person brings a perspective that is informed by their life experiences. It is also possible for someone to represent a stakeholder group to which they do not belong. These people may not share the experiences of the stakeholder group or be able to communicate what the stakeholder group faces directly, but they can still challenge the board to consider the needs of a stakeholder group that is being neglected. The board should ask questions such as: "How would these stakeholders frame the issue and define a successful outcome? What would each group regard as a worst-case scenario?" (Chait et al., 2011, p. 129). In these circumstances, it may require additional effort on the part of the board to reach out to stakeholders so their voices can be directly under-

stood. But if a representative director can get the board to take on this task, they will have represented their constituency group's interest and served the interest of the organization.

\section{CONCLUSION}

According to agency theory, a central role for boards of directors is to ensure the interests of the ownership are paramount in the considerations of management. A strong linkage between the ownership and board provides a valuable tool for ensuring that an organization can fulfill its purpose. While the concept of ownership in the nonprofit sector may not be as clear, this is not an excuse to ignore the important linkages that should exist between the board and the ownership, whether that ownership is the membership, the donors, the clients, the customers, the broader community, or some other group. Indeed, defining an organization's moral ownership can be a valuable task for boards of directors to undertake (Carver, 2006). 


\section{Piscitelli \& Geobey (2020)}

Further research is needed to examine how the separation of operational issues from governance among boards of directors intersects with agency theory. Practical implications should be a major focus of this research. Scholars should begin by examining how nonprofit sector directors conceive their role when representing the ownership. What conflicts do they experience when trying to represent the membership, donors, clients, and/or customers? Researchers should also attempt to develop a list of case studies, tools, and approaches that nonprofit sector organizations are using to respond to and enhance the voices of the ownership. Recommendations from this research could help boards of directors develop new approaches to representing the interests of their ownership.

Further research should examine how the tension between representing ownership and governance manifests itself in the cooperative and municipal sectors. The literature examined here primarily dealt with the nonprofit sector (including nonprofit cooperatives). However, for-profit cooperatives would likely experience many of the same challenges. Municipalities and school boards also warrant special attention. While they technically fit within the category of nonprofit organizations, the election of school board trustees and city councillors through citywide elections makes them unique cases for exploration.

Modern governance theories suggest there is a tension between representing member interests and adhering to governance requirements of nonprofits. However, this distinction is a false dichotomy. Boards can better serve their organizations by representing the membership while adhering to modern governance theories.

Typically, board directors who join a nonprofit for representative reasons are interested in contributing to the organization. Representative directors join the board to make a difference and serve the organization. These directors' efforts can become disruptive if the board is not effective at giving the representative director a voice and guidance. This is particularly common when an issue is brought forward by a representative director, and it is unfortunate because this misplaced debate causes boards to waste energy on triviality when they have an opportunity to make a positive difference. Instead, boards should directly address the principal-agent problem by providing a voice for client stakeholders within the organization. Boards seeking to fulfill their fiduciary obligations would be wise to consider the underlying issues brought forward by representative directors. When a representative director brings up a governance issue, the board should provide space on the agenda to discuss the issue. Even operational concerns raised by representative directors warrant consideration, albeit not in the same way. These issues should be explored for the underlying value that is driving the issue. While the issue itself may be operational in nature, there is almost always an underlying policy or value that has led to the operational concern. In this sense, the representative director has a role that incorporates elements that are similar to those of an elected non-partisan city councillor. When the representative director is heard, rather than being treated as a problem director, they have provided a necessary voice for members, prevented organizational exit, and built loyalty among clients.

\section{REFERENCES}

Block, S.R. (2014). Teaching a course on nonprofit boards of directors and executive leadership using experiential learning theory and simulations. The Journal of Nonprofit Education and Leadership, 4(1), 25-39.

Bradshaw, P., Hayday, B., Armstrong, R., Levesque, J., \& Rykert, L. (2007). Non-profit governance models: Problems and prospects. The Innovation Journal: The Public Sector Innovation Journal, 12(3), 5.1-5.22.

Bradshaw, P., Murray, V., \& Wolpin, J. (1992). Do nonprofit boards make a difference? An exploration of the relationships among board structure, process, and effectiveness. Nonprofit and Voluntary Sector Quarterly, 21(3), 227-249.

Broadbent, A., \& Gucciardi, F. (2017). You're it! Shared wisdom for successfully leading organizations from both a seasoned and a first-time CEO. Toronto, ON: Xephyr Press. 


\section{Piscitelli \& Geobey (2020)}

Brown, W.A. (2005). Exploring the association between board and organizational performance in nonprofit organizations. Nonprofit Management and Leadership, 15(3), 317-339.

Carver, J. (2006). Boards that make a difference: A new design for leadership in nonprofit and public organizations (3d Ed.). San Francisco, CA: Jossey-Bass.

Chait, R.P., Ryan, W.P., \& Taylor, B.E. (2011). Governance as leadership: Reframing the work of nonprofit boards. Hoboken, NJ: John Wiley \& Sons.

Danielson, D. (2017). Local leadership and great governance: We can all make a difference. Saskatoon, SK: Dan Danielson.

Drucker, P.F. (1990). Lessons for successful nonprofit governance. Nonprofit Management and Leadership, 1(1), 7-14.

Drucker, P.F. (2005). Managing the non-profit organization. New York, NY: Routledge.

Fenn, M., \& Siegel, D. (2017). The evolving role of city managers and chief administrative officers. Toronto, ON: Institute on Municipal Finance and Governance.

Gill, M. (2005). Governing for results: A director's guide to good governance. Victoria, BC: Trafford Publishing.

Green, D.P., \& Gerber, A.S. (2008). Get out the vote: How to increase voter turnout. Washington, DC: Brookings Institution Press.

Hall, M.H., \& Reed, P.B. (1998). Shifting the burden: How much can government download to the non-profit sector? Canadian Public Administration, 41(1), 1-20.

Hansmann, H.B. (1980). The role of nonprofit enterprise. The Yale Law Journal, 89(5), 835-901.

Hansmann, H.B. (2013). Ownership and organizational form. In Robert Gibbons \& John Roberts (Eds.), The handbook of organizational economics (pp. 891-917). Princeton, NJ: Princeton University Press.

Herman, R.D., \& Renz, D.O. (1997). Multiple constituencies and the social construction of nonprofit organization effectiveness. Nonprofit and Voluntary Sector Quarterly, 26(2), 185-206.

Herman, R.D., \& Renz, D.O. (2000). Board practices of especially effective and less effective local nonprofit organizations. The American Review of Public Administration, 30(2), 146-160.

Hirschman, A.O. (1970). Exit, voice, and loyalty: Responses to decline in firms, organizations, and states. Cambridge, MA: Harvard University Press.

Houle, C.O. (1990). Governing boards: Their nature and nurture. San Francisco, CA: Jossey-Bass Publishers.

Imagine Canada. (2006). National survey of nonprofit and voluntary organizations: The nonprofit and voluntary sector in Canada. URL: http://www.imaginecanada.ca/sites/default/files/www/en/nsnvo/sector_in_canada_factsheet.pdf [20 July, 2018].

Jensen, M.C., \& Meckling, W.H. (1976). Theory of the firm: Managerial behavior, agency costs and ownership structure. Journal of Financial Economics, 3(4), 305-360.

Levasseur, K. (2018). Co-producing accountability? Drawing conclusions from non-profit child care services in Manitoba. Canadian Public Administration, 61(1), 26-44.

Olson, D.E. (2000). Agency theory in the not-for-profit sector: Its role at independent colleges. Nonprofit and Voluntary Sector Quarterly, 29(2), 280-296.

Phillips, S., \& Levasseur, K. (2004). The snakes and ladders of accountability: Contradictions between contracting and collaboration for Canada's voluntary sector. Canadian Public Administration, 47(4), 451-474.

Ricardo-Campbell, R. (1997). Resisting hostile takeovers: The case of Gillette. Santa Barabara, CA: Greenwood Publishing Group.

Salamon, L.M. (1987). Of market failure, voluntary failure, and third-party government: Toward a theory of governmentnonprofit relations in the modern welfare state. Journal of Voluntary Action Research, 16(1-2), 29-49.

Statistics Canada. (2019, March 5). Non-profit institutions and volunteering: Economic contribution, 2007 to 2017. The Daily. Statistics Canada Catalogue no. 11-001-X. URL: https://www150.statcan.gc.ca/n1/daily-quotidien/190305 /dq190305a-eng.htm [30, May 2019]. 
Piscitelli \& Geobey (2020)

Tschirhart, M., \& Bielefeld, W. (2012). Managing nonprofit organizations. San Francisco, CA: Jossey-Bass. von Schnurbein, G. (2009). Patterns of governance structures in trade associations and unions. Nonprofit Management and Leadership, 20(1), 97-115.

\section{ABOUT THE AUTHORS / LES AUTEURS}

Anthony Piscitelli is a Professor at Conestoga College. Email: apiscitelli@conestogac.on.ca

Sean Geobey is an Assistant Professor at the University of Waterloo and Director of Academic Programs at the Waterloo Institute for Social Innovation and Resilience. Email: sean.geobey@uwaterloo.ca 